https://helda.helsinki.fi

\title{
Early Modern English
}

\section{Nevalainen, Taimi Terttu Annikki}

Oxford University Press

2017-08

Nevalainen , T T A 2017 , Early Modern English . in M Aronoff (ed.) , Oxford Research

Encyclopedias : Linguistics . Oxford Research Encyclopedias , Oxford University Press ,

Oxford . https://doi.org/10.1093/acrefore/9780199384655.013.264

http://hdl.handle.net/10138/310846

https://doi.org/10.1093/acrefore/9780199384655.013.264

unspecified

acceptedVersion

Downloaded from Helda, University of Helsinki institutional repository.

This is an electronic reprint of the original article.

This reprint may differ from the original in pagination and typographic detail.

Please cite the original version. 


\section{Early Modern English}

Terttu Nevalainen

\section{Overview}

In the Early Modern English period (1500-1700) steps were taken towards Standard English, and this was also the time when Shakespeare wrote, but these perspectives are only part of the bigger picture. This chapter looks at Early Modern English as a variable and changing language not unlike English today. Standardization is found particularly in spelling, and new vocabulary was created as a result of the spread of English into various professional and occupational specializations. New research using digital corpora, dictionaries and databases reveals the gradual nature of these processes. Ongoing developments were no less gradual in pronunciation, processes such as the Great Vowel Shift, or in grammar, where many changes resulted in new means of expression and greater transparency. Word-order was also subject to gradual change, becoming more fixed over time.

Key words: spelling standardization, lexical growth, vernacularization, Great Vowel Shift, personal pronouns, progressive aspect, auxiliary do, inverted word-order, multiple negation

\section{Various Traditions}

There is a long tradition of thinking of Early Modern English (EModE) as Shakespeare's English. This line of thought goes back to the $19^{\text {th }}$ century, well before the division of post-medieval English into Early and Late Modern English. Another common approach in the literature has been to view the Early Modern era as a transitional period leading to Standard English. The period has also come to be characterized in functional terms as an era during which the use of the English language spread to all communicative purposes, including science and the law. Related to these developments are advances in communication technologies, notably the impact of printing, which was introduced towards the end of the $15^{\text {th }}$ century.

These various approaches provide different answers to the question of how long a time span the EModE period covers. The answers also depend on whether we look for linguistic or languageexternal factors. Referring to cultural and political landmarks, the six-part Cambridge history of the 
English language begins the period at 1476, when the printing press was introduced to England, and ends it at the American Declaration of Independence in 1776 (Lass 1999). Purely linguistic factors are a good deal harder to pin down. Apart from citing various language-external factors, Görlach (1991, 9-11) justifies his choice of 1500 as the beginning point for his Introduction to Early Modern English by referring to the increased homogenization of spelling and a sharp reduction in inflectional endings. He motivates ending the period at 1700 by pointing to the virtual disappearance of the remaining syntactic redundancies and the rapid re-defining of the existing grammatical categories by that time. However, it is noteworthy that all these features represent processes that do not have exact beginning and end points.

Acknowledging that linguistic periodization is necessarily arbitrary because language change is continuous, EModE is commonly viewed as the period from 1500 to 1700 . This is also how the period is delimited in this chapter, which provides a bird's eye view of some of the major developments in English during these two centuries. These developments will be approached through some of the priorities set by earlier scholarship, showing how they have shaped - and continue to shape - our perceptions of this era in the history of English. ${ }^{1}$

\section{Early Modern English as the language of Shakespeare: bridging the gap}

The first book-length discussions of Early Modern English are two grammars of Shakespeare's language: A Shakespearian grammar by Edwin Abbott (1870) and the more comprehensive Shakespeare-Grammatik by Wilhelm Franz (1898/1899). Abbott specifies his focus in the subtitle of his book: An attempt to illustrate some of the differences between Elizabethan and Modern English ("modern" here referring to Victorian English). Franz (1898: iii) similarly notes that he concentrates on those features in Shakespeare and the language of his period that have since fallen out of use and on those that were not “developed enough" to be understood by a modern educated reader. To bridge the grammatical gap between Shakespeare and his current audiences, more recent grammars such as Blake (2002) and Hope (2003) also continue to address these issues, benefiting from a century of linguistic and literary scholarship on the topic.

There is wide-ranging agreement on a number of grammatical differences between Shakespeare's English and the present day. Scholars identify as particularly archaic, for example, (1) inversion questions, (2) the use of pronouns with imperatives and (3) of modal auxiliaries as main verbs, but they also note that these and many other features display a fair amount of variation even with one 
and the same play (Busse \& Busse 2012: 817; their examples). In many cases this variation could be taken as an indication of ongoing change in the language in Shakespeare's day.

(1) What makes he heere? (Othello I.ii.59)

(2) Then go we near her (Much Ado about Nothing III.i.32)

(3) I can no more (Hamlet V.ii.312)

While grammatical differences are relatively easy to discover and describe, vocabulary presents challenges of a different kind, most of them to do with the data sources available to researchers. Views of Shakespeare's lexical innovativeness range from finding him the "greatest word-maker of them all” (Shipley 1977: 28) to a perfectly average or even “almost aggressively normal” word-user (Syme 2011). New resources such as the Early English books online (EEBO) have helped update views on Shakespeare's neologisms based on historical dictionaries. Using this resource that contains digital copies of most books printed in England before 1700, it is possible to explore the contemporary print record of words and review their datings given in historical dictionaries.

One of the neologisms attributed to Shakespeare is courtship (Garner 1982). It appears in 1,599 documents in EEBO. The first occurrence is found in Anthony Munday's 1588 translation Palmerin D'Oliua ("Why Sir Knight, where learned you so little courtship...”). Shakespeare makes use of the word in the 1590s in Richard II, Romeo and Juliet and Love's labour's lost, but so do George Peel, Thomas Nashe and George Chapman in their plays published a few years before Shakespeare's. Some scholars argue for an earlier date for Love's labour's lost and suggest that a lost version may go back to 1588, the same year as Munday’s text (Goodland 2011, note 2). But publication dates do not tell the whole story about lexical growth, and a number of other issues will need to be considered when counting coinages. Ward and Valenza (2011: 49) list some of them:

Counting coinages has most of the problems of counting other words - making due allowance for corpus size, latency, inflections, multiple meanings and so on - plus special problems of its own, which are harder to do with computers and have been less explored: sorting out what counts as a word, whether it is one person's real coinage, and not another's, and deciding whether it has caught on.

There is thus more to bridging the lexical gap between Shakespeare and his modern audiences than looking for neologisms. 
Describing what Shakespeare's language might have sounded like presents problems of yet a different kind: in the absence of any spoken records, the evidence has to be deduced from writing (spelling, rhymes, metrical evidence and metatextual commentary). Accounts of Shakespearian pronunciation have been compiled to serve both scholarly aims (Kökeritz 1953, Cercignani 1981) and the practical purposes of performing Shakespeare in the original pronunciation (Crystal 2005). Opinions are nonetheless divided as to the degree to which the pronunciation of Shakespearean drama can be recreated and understood today (for some views, see Nevalainen 2006: 118-119).

\section{Towards a Standard English: spelling and vocabulary}

One of the recurrent topics of scholarly discussion of EModE is concerned with the standardization of the English language in that period. This is the story told in most textbooks from Wyld (1920) to Freeborn (1998) and many more. Wyld describes his object of study as follows:

... it may be called Good English, Well-bred English, Upper-class English, and it is sometimes, too vaguely, referred to as Standard English. For reasons which will soon appear, it is proposed here to call it Received Standard English. (Wyld 1920: 2, original emphasis)

In tracing the history of Standard English, Wyld took a particular interest in pronunciation. He assumed that a spoken standard must have existed from the first half of the $16^{\text {th }}$ century on, but also admitted that it allowed more variation than today and was largely confined to the Royal Court (Wyld 1920: 103). Both Wyld (1920: 103) and Feeborn (1998) date modern-style standard pronunciation to the $18^{\text {th }}$ century.

\subsection{Spelling}

If by a standard language we understand a variety with minimal variation in form and maximal variation in use, spelling is a much better candidate for Early Modern Standard English than speech. ${ }^{2}$ Spelling regularization can be approached as a process of focusing that had started around the mid- $14^{\text {th }}$ century, when English gained new functions as a written language. Both professional copyists and printers were instrumental in spreading southern forms and spelling conventions to the rest of the country. But the process was not straightforward: arising from the concerns of the teaching profession, the question of a spelling reform sparked heated debates in the $16^{\text {th }}$ century. Those in favour of a reform argued that English spelling had become too far removed from the pronunciation of the language and that a closer connection should be (re-)established. Those 
supporting established usage countered them by arguing that there was too much variation in speech to form a basis for a renewed orthography.

New means of regularizing established spelling conventions were introduced to show the "right writing” of words, notably word lists appended to teaching manuals such as Richard Mulcaster's Elementarie (1582). When analysing this list of c. 8,500 common English words, Barber (1997: 86) found that over half of them are identical with their modern standard spelling and considerably more if the regular $\langle\mathrm{i}>|<\mathrm{j}>$ and $\langle\mathrm{u}>\mid<\mathrm{v}\rangle$ alternations (see below) are excluded from the calculation.

Teaching manuals and spelling books made an important contribution to fixing English spelling norms in the $17^{\text {th }}$ century. One worth mentioning is Edmund Coote's The English schoole-maister (1596), which offers not only syllable and word lists displaying spelling rules but also a 1,400-word dictionary. Scragg (1974: 78-80) attributes part of the success of Coote’s manual - it went through some fifty editions in the $17^{\text {th }}$ century - to his method of selecting for each word the spelling that was most common in print. Coote promoted, for example, spellings such as seem and seen instead of seme and sene proposed by Mulcaster (1582)

In the course of the $17^{\text {th }}$ century the $<\mathrm{u}>/<\mathrm{v}>$ alternation $(<\mathrm{v}>$ being used word-initially and $<\mathrm{u}>$ word-medially for both the vowel and the consonant) was also regularized to its modern standard form. Figure 1 shows the crossing-over from the previously regular word-medial $<\mathrm{u}>$ to $<\mathrm{v}>$ in have in the EEBO-TCP database between the 1620s and 1640s. A similar process took place around the same time with the former use of $<\mathrm{i}>$ for both $>\mathrm{i}>$ and $<\mathrm{j}>$. 


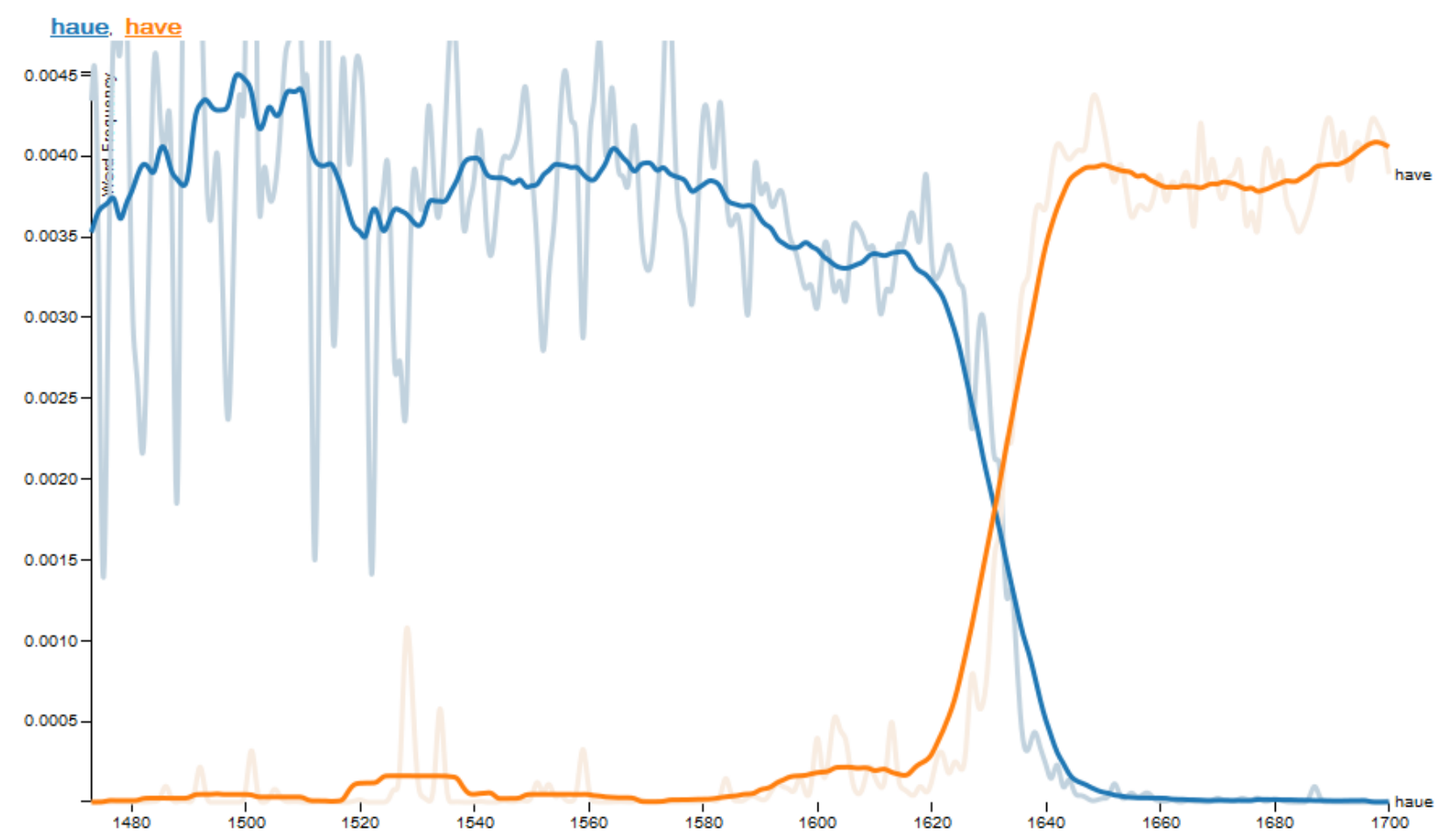

Figure 1. Regularization of the $<\mathrm{u}>/<\mathrm{v}>$ alternation in $17^{\text {th }}$-century print: $<$ haue $>/<$ have $>$. (http://earlyprint.wustl.edu/eebotcpngrambrowser.html)

These processes apply to spelling regularization in print, which displays remarkable stability by the mid $-17^{\text {th }}$ century. The same cannot be said about private spelling habits, which show much more variation depending on the writer's level of education. Moreover, punctuation and capitalization are standardized later than spelling in print as well. For example, the apostrophe only begins to be used to signal the possessive $-s$ in the $17^{\text {th }}$ century, earlier in the singular than in the plural, but it can mark the elision of the vowel in regular past participle forms (e.g. us'd for used) well into the Late Modern English period.

Looking at the big picture, Baron, Rayson \& Archer (2009) calculated the relative frequencies of spelling variants over time in several corpora and databases, covering the period from 1400 to 1800 and including the Shakespeare Corpus and the EEBO database. On average, their data showed variation in some $50 \%$ of word types towards the end of the $16^{\text {th }}$ century, and at the end of the $17^{\text {th }}$ century variation was still found in about $20 \%$ of word types but in less than $10 \%$ of word tokens. ${ }^{3}$ 


\subsection{Vocabulary}

Automatic studies of spelling variation do not necessarily take into account the growth of English vocabulary over time, which vastly increases the number of rare words in the language in the $16^{\text {th }}$ and $17^{\text {th }}$ century. Vocabulary growth represents the widening range of domains of the vernacular, thus showcasing the tendency of a standardizing language to maximal variation in use. Lancashire (2012: 637) writes that “[t]he mother tongue remained small, well under 10,000 words, until the 17th century. Printed books, however, by saving and disseminating learned and technical words, expanded available vocabulary by $75 \%$ from 1500 to 1600 ”.

Various aspects of this growth have been explored using the Oxford English dictionary. Work on the new edition of this lexical resource $(O E D 3)$ suggests that twice as many words were first recorded between 1550 and 1699 as in the previous 150 years from 1400 to 1549 (Durkin \& Allan 2016: 72). Dividing the EModE period into fifty-year subperiods, Durkin (2014: 34) shows that the frequency of new words peaks in the first half of the $17^{\text {th }}$ century. Figure 2 presents a very similar overview based on the Chronological English dictionary (CED; Wermser 1976: 23; see Nevalainen 1999: 336-339). Lancashire (2012: 641) predicts that the process of antedating OED headwords "is spreading vocabulary growth out more evenly through the Tudor period and may diminish the 'acceleration' effect” found in the $16^{\text {th }}$ century. ${ }^{4}$

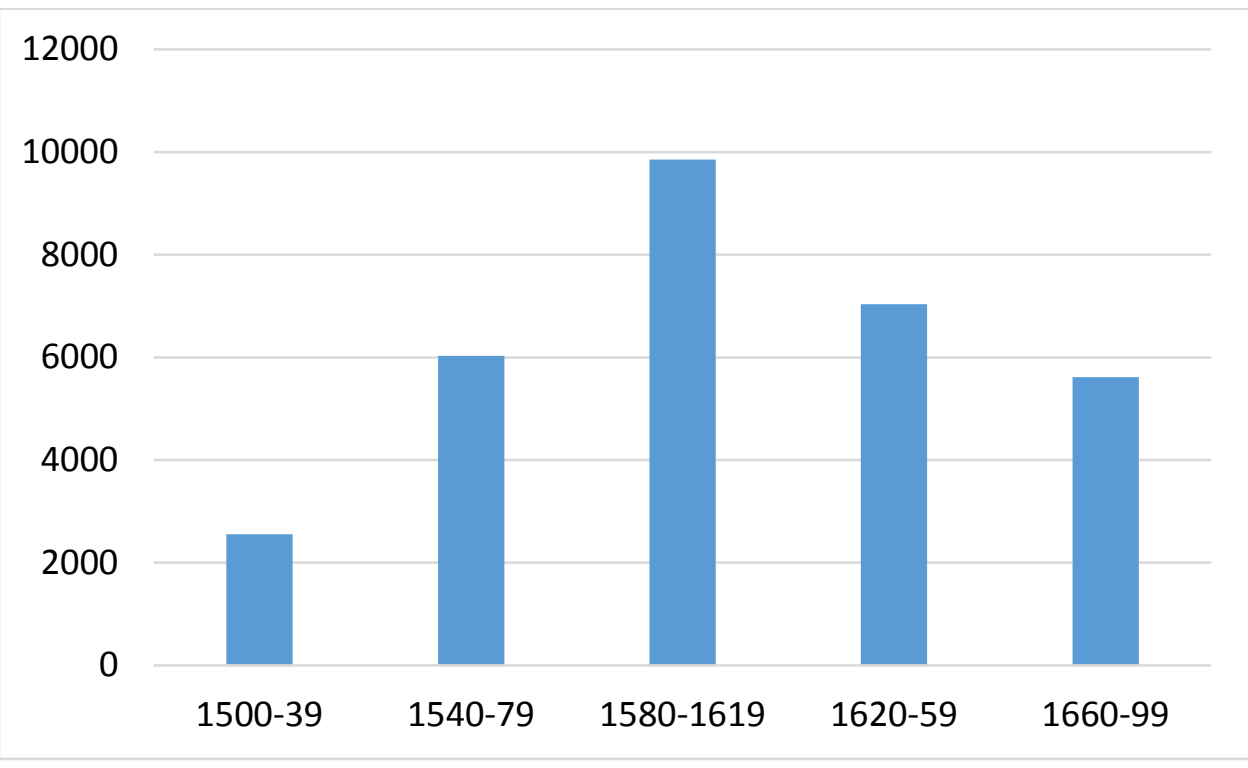

Figure 2. Lexical growth in English 1500-1700. 
Lexical innovations reflect the ongoing processes of modernization and vernacularization in the EModE period. The vernacular gained currency in a wide variety of specialist fields and replaced Latin and French, for example, in many legal, religious and scientific domains. The growing range of specializations of contemporary knowledge is recorded in monolingual dictionaries and glossaries, which covers fields as diverse as alchemy and architecture, classics and cosmography, fencing and heraldry, hunting and falconry, mathematics and minerals, philosophy and poetics, and weights and measures (Nevalainen 1999: 342-347).

As English was spreading to a widening range of discourses, including the most prestigious ones, the "insufficiency" of the mother tongue became a common cause of complaint: English was felt to lack the prestige of Latin or French as a language of learning and literature. As a result, several often competing methods of vocabulary expansion were adopted, including both borrowing and coinages based on native word formation processes (Nevalainen 1999: 336-342). These means were used to introduce new lexis to meet the needs of vernacularization but also to consciously enrich and embellish the language. Deliberate learned loans also met with opposition and were branded as "inkhorn” terms (with reference to the common inkwell originally made of a horn).

One of the early borrowers of the utilitarian kind was Sir Thomas Elyot, a scholar and diplomat. Most of the loans he used come from the classical languages, and include a number of words that are still current, such as encyclopaedia, frugality, metamorphosis, modesty and persist (Barber 1976: 79). He was also among the first to use education in print (ex. 4):

(4) The education or fourme of bryngynge vp of the chylde of a gentylman, whiche is to haue auctoritie in a publyke weale. (Thomas Elyot, [1531]1537, The boke named the Gouernour, 15v.)

Reflecting its cultural dominance at the time, Latin was indeed the primary source of borrowed lexis in EModE (Durkin 2014: 255-269). Beginning with Robert Cawdey’s A table alphabeticall (1604), specialist vocabulary started to be coded in "hard-word" dictionaries in the $17^{\text {th }}$ century for the benefit of the vast majority of the population who would not understand words borrowed from “Hebrewe, Greeke, Latine, or French”, as Cawdrey pointed out in his preface. In The English dictionarie (1623), Henry Cockeram also introduced a large number of new words into English by anglicizing Latin entries in Thomas Thomas’s Latin-English dictionary.

Borrowing often resulted in native and borrowed lexemes co-occuring in the same lexical sets. Loan words typically appeared in technical uses, as in the following word pairs, where the first member 
has its roots in Old English and the second in Latin or French (the fields and dates come from the EEBO database): belly/ventral (fiction 1693, medicine 1695), book/bibliography (religious miscellany 1664), egg/ovum (biology 1672), naked/nudity (zoology 1607), saying/dictum (poetry 1586) and sun/heliocentric (travel, 1667). It is noteworthy that loan words did not necessarily have the same meaning as they have today. Bibliography, for example, was first introduced in the sense of 'the writing of books’ (Nevalainen 1999: 362-364).

The case of ovum nicely illustrates the prevalence of Latin in the English print culture at the time: its first occurrence in the EEBO database goes back to a dietary guide from 1599, where it simply provides the Latin term for egg in a header. Well into the $17^{\text {th }}$ century the word appears in Latin passages or collocates such as malum ovum ('bad egg') in a wide variety of sources ranging from treatises on embryology, natural history and theology to Latin-English dictionaries and textbooks. It appears as an integrated specialist term in English in the latter half of the century, the $O E D$ dating this technical use in Philosophical transactions to 1672.

The fact that specialist terms are well documented does not mean that they have survived until the present. Analysing The shorter Oxford English dictionary, Neuhaus (1971) found that between 1460 and 1620 many more new words were introduced than old ones lost. By contrast, between 1640 and 1680, words introduced after 1530 showed a higher than average rate of disappearance. This comparison suggests that the intensive period of vocabulary enrichment was followed by a corresponding increase in obsolete words. Most of them disappeared during their first decade, and many were cited only once. It would appear that they had never made it to wider use. This was true of one third of the Latinate neologisms attributed to Shakespeare and of a large number of coinages introduced by lexicographers like Cockeram (1623), who endeavoured to enrich the EModE lexicon with parallel formations (Nevalainen 1999: 340-341, 349).

Measured in terms of the intake of new words, lexical standardization remains an abstraction. It does not take place in a cultural vacuum but constitutes an ongoing process with both gains and losses and takes its time to be integrated into actual use. Importantly, the expanding vocabulary of EModE did not become the property of the population at large but, as Lancashire (2012: 643) notes, it rather shows the growth of an increasing variety of occupational sociolects. 


\section{A variable and changing language: pronunciation and grammar}

\subsection{Pronunciation}

If vocabulary growth did not directly affect all English speakers in the EModE era, changes in pronunciation and grammar did. As noted above, pronunciation can only be reconstructed from written evidence before it was integrated into monolingual English dictionaries using a systematic phonetic notation in the $18^{\text {th }}$ and $19^{\text {th }}$ centuries. Although there is a fair amount of commentary provided by early phoneticians and orthoepists, it is far from unproblematic. Lass (1999: 59) notes that we have to discriminate between:

those who understood the difference between sound and spelling and those who didn't, those whose normative biases led them to propose purely 'theoretical' and non-existent pronunciations and more objective observers, etc.

Despite these problems of primary evidence, there are comprehensive studies, such as Dobson (1968), which derive their evidence from contemporary EModE grammarians, phoneticians and spelling reformers.

Scholarly opinion agrees that while some major changes happened in the EModE vowel system, the consonant system remained comparatively stable. ${ }^{5}$ In all varieties, /r/ was pronounced after the vowel (car, door). There is, however, occasional evidence for $/ \mathrm{r} /$-deletion in private writings (e.g. skasely 'scarcely') and some phonetic weakening of $/ \mathrm{r} /$ in the $17^{\text {th }}$ century. By contrast, $/ \mathrm{h} /$-dropping was common word-initially in weakly-stressed words such as pronouns (e.g. hit $>$ it). It was commonly dropped in French loan words (history, honour) but often reintroduced into these words on etymological grounds. Dialectally /h/ could also be dropped from words of Germanic origin, such as hand and heart. Chronicling public events in $16^{\text {th }}$-century London, Henry Machyn, a merchant tailor, spells hard without an $<\mathrm{h}>$ but inserts one into playing so that it becomes plahyng (ex. 5; Nevalainen 2006, 127). Shakespeare and other dramatists often drew on /h/-dropping and /h/-insertion for puns (air, hair, heir).

(5) the Quen['s] grace toke her barge at Whyt hall ... and so crost over to London syd with drumes and trumpetes playhyng ard be-syd, and so to Whyt hall agayne to her palles. (HC, Henry Machyn, Diary, 1553-59, 201) 
Just like today, unstressed syllables could be dropped in connected speech and grammatical words assume their contracted forms (they are > they're). But preceding an auxiliary, the pronoun it was clipped (it is > 'tis), not the verb as today (it's).

Most dramatic changes took place in stressed syllables, as long vowels were redistributed in a series of processes which resulted in what is known as the Great Vowel Shift (GVS). The process was probably set in motion by the high vowels /i:/ and /u:/ in the late 15th century: the front vowel /i:/ came to acquire the quality of /ei/, and the back vowel /u:/ the quality of /ou/. The outcome was that words like /li:f/ (life) and /ti:m/ (time) were pronounced as /leif/ and /teim/, and /hu:s/ (house) and /u:t/ (out) as /hous/ and /out/.

The rest of the long vowels systematically moved up one step in the vowel space: words with the high-mid front vowel /e:/ (meet, see) came to be pronounced with the high vowel /i:/and the highmid back vowel /o:/ (do, loose) with /u:/. Words pronounced with the low-mid front vowel / $\varepsilon: /$ (meat, sea) in turn acquired the closer quality of /e:/ and those that had the back vowel /o:/ (boat, rose) were raised to /o:/. Finally, the low /a:/ vowel in words like make and name rose to low-mid $/ \varepsilon: /$.

It is noteworthy that the Great Vowel Shift was not completed in the northern dialects, where it affected the front vowels but not all back vowels. Long vowels also emerged from diphthongs (i.e. vowels with a changing quality). In almost all these changes a Middle English diphthong was reduced to a pure long vowel. These processes resulted in vowel mergers, and many word pairs came to sound alike (see further Lass 1999).

\subsection{Grammar}

Unlike pronunciation, grammar change can be observed in most genres and registers, from formal kinds of writing such as statutes to informal kinds such as comedy. Personal communication is available in correspondence and approximate records of speech in trial proceedings. The EModE section of the Helsinki Corpus of English Texts (HC) comprises fifteen different genres and has provided primary data for a large number studies on EModE grammar. The Corpus of Early English Correspondence (CEEC) in turn enables systematic historical sociolinguistic research into the Early Modern period, and speech-based data is included in the Corpus of English Dialogues (CED). ${ }^{6}$

There are some broad trends that characterize many processes of grammatical change in EModE. One of the most conspicuous is greater transparency. This analytic trend is found in many of the 
new forms and constructions that emerge in competition with older, more synthetic expressions in different grammatical domains. At the same time, certain grammatical distinctions are lost altogether. $^{7}$

There are both gains and losses in the EModE system of personal pronouns. Perhaps the most noticeable loss is the second-person singular pronoun thou being replaced by the plural form you. Originally the polite form of address, you is the common form found, for example, in personal correspondence throughout the period, and thou only occurs in letters written by mothers to their children and by husbands to their wives. Example (6) shows both of them occurring in the same letter. Based on dialogues ranging from court proceedings to comedy, Walker (2007) draws the conclusion that social superiors could address their inferiors with thou but inferiors replied to them with you.

(6) I read thy Letters over and over and over, for in them I see thee as well as I can. I am thine as much as possibly. I hope our Children are well. My service to all you think fitting to speake it to. (HC, Henry Oxinden to Katherine Oxinden, 1662; The Oxinden and Payton letters, 274)

The generalization of you for singular as well as plural addressees also meant a loss in the number contrast in $2^{\text {nd }}$-person pronouns. The case contrast between the subject form ye and object form you was also lost and you began to be used in both functions. This process was completed in data sources such as personal letters in the $16^{\text {th }}$ century, but ye was retained dialectally much longer, for example, in northern regional varieties, as indeed was thou.

Two other changes are connected with the trend of making a distinction between personal and nonpersonal reference. The personal pronoun system was enriched by the introduction of the neuter possessive pronoun its at the end of the 16th century. It replaced the historical form his, which had been used for both masculine and neuter referents, as in (7).

(7) The Arctique Circle ... hath his name of this worde Arctos, which is the great Beare ... (HC, Thomas Blundeville, 1597; The Tables of the three speciall right lines belonging to a circle, 156r)

The same principle is manifest in the restriction of the relative pronoun which to non-human referents. The older use is still found in example (4), above: the chylde of a gentylman, whiche is 
to haue auctoritie. In the course of the $16^{\text {th }}$ and $17^{\text {th }}$ century it came to be replaced by who, which alternated with the older that, as it continues to do today.

Verb forms also underwent changes. Verbal -s gradually replaced -th in the third-person present singular indicative (e.g. it cometh $>$ it comes) and are replaced be in the present indicative plural of the verb to be. These forms were both originally northern dialect features. The southern forms were retained dialectally and in formal written contexts much longer than in speech (cf. the powers that $\boldsymbol{b} \boldsymbol{e}$ in the Tyndale Bible, 1534). Verbal constructions were also established, providing grammatical means of expressing the progressive aspect $(b e+-i n g)$ and indicating future time by means of the be + going to construction. They are illustrated (11) and (12), respectively. The new expression of future time was added to earlier ones, such as the auxiliaries shall and will.

(11) My Lady Anne Wentworth I heare is marryeing but I cannot Learne to whome ... (CEEC, Dorothy Osborne, 1653; The letters of Dorothy Osborne, 32)

(12) $\mathbf{S}^{\mathbf{r}}$ John Walter is going to be marryed to my Lady Stoel, $\mathrm{w}^{\mathrm{ch}}$ will be very happy for him. (HC, Anne Hatton, 1695; Correspondence of the Family of Hatton, 214)

A number of developments were connected with the order of sentence elements. The subject-verbobject order, the verb following the subject, was established as the basic word-order type in EModE declarative sentences. The inverted order was still found after adverbs like here, now, then and thus (13), but also after longer sentence elements. Bækken (1998: 60) estimated that the rate of inversion fell from the average of one inverted declarative main clause in five in 1500 to one in ten in 1700 .

(13) and thus stande they in altercation, not like to agree, as many thynck. (CEEC, Henry Southwick, 1545; The Johnson letters 1542-1552, 338)

A converse development took place with initial negative elements such as neither, never and nor, which started to require inversion in declarative sentences. This process also supported the rise of the auxiliary do in negative contexts. Examples (14) and (15) show how an individual who used the inverted word order after neither changed from main-verb inversion (14) to auxiliary inversion by means of $d o$ (15). The presence of an auxiliary also prevents the inversion of the subject and the main verb in interrogative sentences, and maintains the regular verb-object order in negative sentences. 
(14) Sir, After so longe silence I am out of my bias, and know not where to begin, neither know I what is new or what is old to you ... (CEEC, John Chamberlain, 1605; The letters of John Chamberlain I, 208)

(15) but now there is no remedy, neither do they know how or whether to send yt after him. (CEEC, John Chamberlain, 1617; The letters of John Chamberlain II, 102)

The introduction of do into the verb phrase makes it more transparent as the auxiliary then carries features such as tense (present v. past), mood (indicative v. subjunctive) and polarity (affirmative v. negative). In the absence of another auxiliary, the use of $d o$ was first generalized in questions and, in particular, negative questions in the course of the EModE period. The process took longer in negative statements, where do was used in about two thirds of the cases with most verbs at the end of the $17^{\text {th }}$ century.

Running counter to this trend, do failed to become a regular feature in affirmative statements. After picking up in the $16^{\text {th }}$ century this use declined sharply in the course of the 17 th century. At the height of its popularity it was common in both emphatic and non-emphatic uses, and in formal and informal contexts, as in (16) and (17), while today it is used systematically only for emphasis and contrast in this sentence type. It has been suggested that the rapid decline of $d o$ in affirmative statements was due to dialect contact or that it may have been a manifestation of some more abstract grammatical processes of change, but no definitive answer has been proposed so far (Warner 2012).

(16) The buyldinges of your noble colledge most prosperouslye and magnyfycently dothe arryse in suche wise that ... (Thomas Cromwell, 1528; Life and letters of Thomas Cromwell, Vol. 1, 319)

(17) I se by thy last letter thow dost desire much to se me (CEEC, Katherine Paston, 1625; The Correspondence of Lady Katherine Paston 1603-1627, 82)

The grammar of negation also underwent changes. Like today, not was used to negate the sentence in the $16^{\text {th }}$ century but, when associated with indefinite expressions, it was often accompanied by other negative forms (no, never) rather than their non-assertive counterparts (any, ever). Multiple negation occurred in the writings of educated and uneducated people alike. The examples below come from the corpus of personal letters and date to the 1540s. The passage in (18) was written by a merchant's wife, and those in (19) and (20) by a bishop. Although the writers show different 
degrees of spelling variation, reflecting their differences in education, both of them use multiple and single negation side by side.

(18) Har answar was that she wold not set har myend to no man tell she was delyvered and choirched, and than as God shall provyde for har [...] in nowise she wold make me any grant that my brother shold com to har ... (CEEC, Sabine Johnson, 1545; The Johnson letters 1542-1552, 396)

(19) He said he could not facion hymself noon other commission thenne he hath, and he wold it wer such as might please your Majestie to accepte. (CEEC, Stephen Gardiner, 1542; The letters of Stephen Gardiner, 94 -95)

(20) as I have bifore said, that I cannot take any counforte in it. (CEEC, Stephen Gardiner, 1545; The letters of Stephen Gardiner, 189)

As shown by Figure 3, during the EModE period multiple negation as good as disappeared from simple contexts with indefinite pronouns like those in (18) to (20) in the personal correspondence of literate people. It was retained in co-ordinate constructions such as not ... neither into the Late Modern English period. The use of multiple negation was also socially stratified: although it was generally on its way out, it disappeared from the language of the lower social ranks more slowly than from the higher and professional social strata (Nevalainen \& Raumolin-Brunberg 2007: 71-72, 145-146). Like many other recessive features, multiple negation persisted regionally and was stigmatized by prescriptive grammarians in the $18^{\text {th }}$ century.

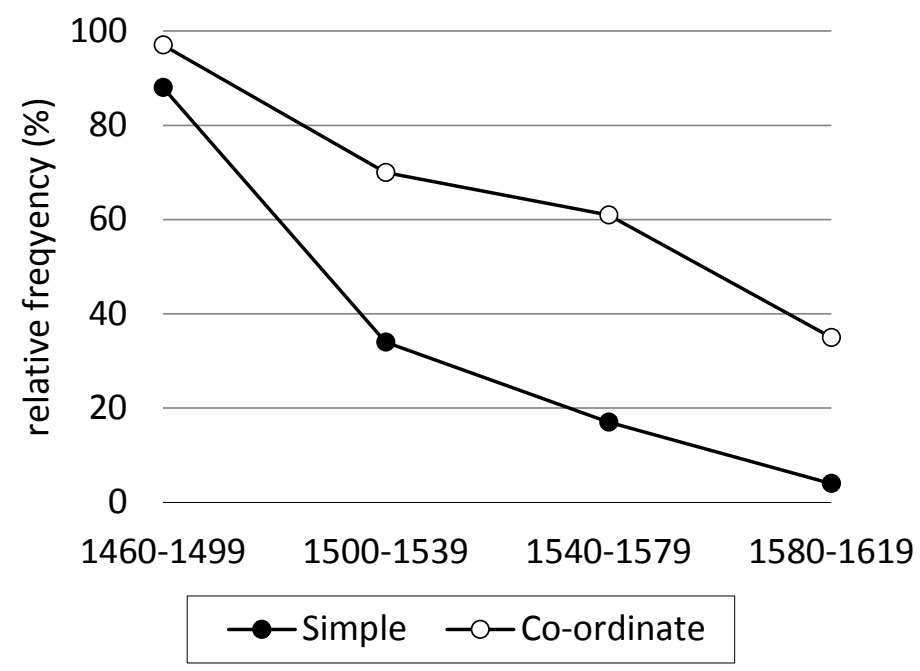

Figure 3. Decline of multiple negation in simple and co-ordinate constructions (CEEC). 


\section{Expansion of English}

It was not only the language that was transformed in the EModE period but remarkable developments can also be seen in the numbers and mobility of the speakers of English at the time (Nevalainen 2006: 140-148).

In 1500, the population of England and Wales was just over 2 million inhabitants. Two hundred years later in 1700, it reached 5 million. English was spoken not only in England and Wales but also in Ireland, and Scots-English was spoken in Scotland. These areas were still bilingual as the Celtic languages (Welsh, Irish, and Scots Gaelic) predominated outside England. As the period advanced, English gained a strong position throughout the British Isles and was also transported to North America. The estimated number of emigrants to the New World was about 400,000 in the 17th century. How the language diversified as a result of these developments would be the topic of a chapter of its own. 


\section{Notes}

1. There are three textbooks that discuss the Early Modern English period from 1500 to 1700 (Barber [1976]1997, Görlach 1991, and Nevalainen 2006).

2. See further Scragg (1974), Salmon (1999) and Lancashire (2010). I discuss spelling standardization in Nevalainen (2006: 31-37) and in Nevalainen (2012).

3. The authors note that their results represent only approximate values because of the difficulties involved in automatic processing of spelling variants. Particular problems are caused by proper nouns, capitalization and the use of foreign languages.

4. For quantitative information on lexical growth, see further Lancashire (2010) and on loan words, Durkin (2014) at: http://blog.oxforddictionaries.com/2014/03/borrowed-words/.

5. The following discussion is based on Nevalainen (2006: 118-131).

6. The Helsinki Corpus of English Texts (1991). Compiled by Matti Rissanen (Project leader), Merja Kytö (Project secretary); Leena Kahlas-Tarkka, Matti Kilpiö (Old English); Saara Nevanlinna, Irma Taavitsainen (Middle English); Terttu Nevalainen, Helena Raumolin-Brunberg (Early Modern English). Helsinki: University of Helsinki. http://www.helsinki.fi/varieng/CoRD/corpora/HelsinkiCorpus/index.html.

The Corpus of Early English Correspondence. 1998. Compiled by Terttu Nevalainen and Helena Raumolin-Brunberg (Project leaders); Jukka Keränen, Minna Nevala, Arja Nurmi \& Minna Palander-Collin. Helsinki: University of Helsinki. http://www.helsinki.fi/varieng/CoRD/corpora/CEEC/index.html.

A Corpus of English Dialogues 1560-1760. 2006. Compiled under the supervision of Merja Kytö (Uppsala University) and Jonathan Culpeper (Lancaster University). http://www.helsinki.fi/varieng/CoRD/corpora/CED/index.html.

7. The discussion in this section adopts a broad view of grammar and includes both morphology and syntax. See further Rissanen (1999), Görlach (1991: 79-135), Barber (1997: 142-218), Nevalainen (2006: 73-117), Culpeper \& Kytö (2010: 184-198) and, for a sociolinguistic perspective, Nevalainen \& Raumolin-Brunberg (2017). 


\section{Further Reading}

Barber, Charles (1997). Early Modern English. $2^{\text {nd }}$ ed. (1 ${ }^{\text {st }}$ ed. 1976.) Edinburgh: Edinburgh University Press.

Blake, Norman F. (2002). A grammar of Shakespeare’s language. Basingstoke: Palgrave.

Lass, Roger (Ed.). The Cambridge history of the English language, Vol. 3, 1476-1776. Cambridge: Cambridge University Press.

Nevalainen, Terttu (2006). An introduction to Early Modern English. Edinburgh: Edinburgh University Press.

Nevalainen, Terttu \& Raumolin-Brunberg, Helena (2017). Historical sociolinguistics: Language change in Tudor and Stuart England. $2^{\text {nd }}$ edition. London, \& New York: Routledge.

\section{Critical Analysis of the Scholarship}

\section{References}

Abbott, Edwin A. (1870). A Shakespearian grammar: An attempt to illustrate some of the differences between Elizabethan and Modern English. Mineola, New York: Dover Publications, Inc.

Bækken, Bjørg (1998). Word order patterns in Early Modern English. Oslo: Novus Press.

Barber, Charles (1997). Early Modern English. $2^{\text {nd }}$ ed. (1 ${ }^{\text {st }}$ ed. 1976.) Edinburgh: Edinburgh University Press.

Baron, Alistair, Rayson, Paul \& Archer Dawn (2009). Word frequency and key word statistics in historical corpus linguistics. Anglistik: International Journal of English Studies 20, 41-67.

Blake, Norman F. (2002). A grammar of Shakespeare’s language. Basingstoke: Palgrave.

Busse, Ulrich \& Busse, Beatrix (2012). Early Modern English: The language of Shakespeare. In Alexander Bergs \& Laurel Brinton (Eds.), English historical linguistics: An international handbook, Volume 1 (pp. 808-826). Berlin: De Gruyter Mouton. 
Cawdrey, Robert (1604). A table aphabeticall. London: I. R. for E. Weaver.

Cercignani, Fausto (1981). Shakespeare's works and Elizabethan pronunciation. Oxford: Clarendon Press.

Cockeram, Henry (1623). The English dictionarie, or, An interpreter of hard English words. London: N. Butter.

Coote, Edmund (1596). The English Schoole-maister. London: Printed by the Widow Orwin for Ralph Iackson and Robert Dexter.

Culpeper, Jonathan \& Merja Kytö (2010. Early Modern English dialogues: Spoken interaction in writing. Cambridge: Cambridge University Press.

Crystal, David (2005). Pronouncing Shakespeare: The Globe experiment. Cambridge: Cambridge University Press.

Dobson, Eric J. ([1957]1968). English pronunciation 1500-1700. Oxford: Clarendon Press.

Durkin, Philip (2014). Borrowed words: A history of loanwords in English. Oxford: Oxford University Press.

Durkin, Philip \& Allan, Kathryn (2016). Borrowing and copy. In Anita Auer, Victorina GonzálezDíaz, Jane Hodson \& Violeta Sotirova (Eds.), Linguistics and literary history: In honour of Sylvia Adamson (pp. 71-86). Amsterdam \& Philadelphia: Benjamins.

Franz, Wilhelm (1898/99). Shakespeare-Grammatik. Halle a. S.: Max Niemeyer.

Freeborn, Dennis (1998). From Old English to Standard English: A course book on language variation across time. $2^{\text {nd }} \mathrm{ed}$. Ottawa: University of Ottawa Press.

Garner, Bryan (1982). Shakespeare’s Latinate neologisms. Shakespeare Studies, 15, 149-170.

Goodland, Giles (2011). 'Strange deliveries': Contextualising Shakespeare’s first citations in the OED. In: Mireille Ravassat \& Jonathan Culpeper (Eds.), Stylistics and Shakespeare's language (pp. 8-33). London \& New York: Continuum.

Görlach, Manfred (1991). Introduction to Early Modern English. Cambridge: Cambridge University Press. 
Hope, Jonathan (2003). Shakespeare’s grammar. London: The Arden Shakespeare.

Kökeritz, Helge (1953). Shakespeare’s pronunciation. New Haven, CT: Yale University Press. Lancashire, Ian (2010). Why did Tudor England have no monolingual English dictionary? In John Considine (Ed.), Webs of words: New studies in historical lexicology (pp. 8-23). Newcastle upon Tyne: Cambridge Scholars Publishing.

Lancashire, Ian (2012). Early Modern English: Lexicon and semantics. In Alexander Bergs \& Laurel Brinton (Eds.), English historical linguistics: An international handbook, Vol. 1 (pp. 637652). Berlin: De Gruyter Mouton.

Lass, Roger (1999). Phonology and morphology. In Roger Lass (Ed.), The Cambridge history of the English language, Vol. 3, 1476-1776 (pp. 56-186). Cambridge: Cambridge University Press.

Mulcaster, Richard (1582). The first part of the Elementarie which entreateth chefelie of the right writing of our English tung. London: T. Vautroullier.

Neuhaus, Hans Joachim (1971). Towards a diachronic analysis of vocabulary. Cahiers de lexicologie, 18, 29-42.

Nevalainen, Terttu (1999). Early Modern English lexis and semantics. In Roger Lass (Ed.), The Cambridge history of the English language, Vol. 3, 1476-1776 (pp. 332-358). Cambridge: Cambridge University Press.

Nevalainen, Terttu (2006). An introduction to Early Modern English. Edinburgh: Edinburgh University Press.

Nevalainen, Terttu (2012). Variable focusing in English spelling between 1400 and 1600. In Susan Baddeley \& Anja Voeste (Eds.), Orthographies in Early Modern Europe (pp. 127-165). Berlin \& Boston: De Gruyter Mouton.

Nevalainen, Terttu \& Raumolin-Brunberg, Helena (2017). Historical sociolinguistics: Language change in Tudor and Stuart England. $2^{\text {nd }}$ edition. Loondon \& New York: Routledge.

Oxford English dictionary. OED Online. Oxford: Oxford University Press. http://www.oed.com/view/Entry/256787 (accessed 12 December, 2016). 
Rissanen, Matti (1999). Syntax. In Roger Lass (Ed.), The Cambridge history of the English language, Vol. 3, 1476-1776 (pp. 187-331). Cambridge: Cambridge University Press.

Salmon, Vivian (1999). Orthography and punctuation. In Roger Lass (Ed.), The Cambridge history of the English language, Vol. 3, 1476-1776 (pp. 13-55). Cambridge: Cambridge University Press. Scragg, D.G. (1974). A history of English spelling. Manchester: Manchester University Press.

Shipley, Joseph T. (1977). In praise of English: The growth \& use of language. New York: Times Books.

Syme, Holger (2011). Shakespearean mythbusting I: The fantasy of the unsurpassed vocabulary. http://www.dispositio.net/archives/501 (accessed 14 December 2016).

Walker, Terry (2007). Thou and you in Early Modern English dialogues: Trials, depositions, and drama comedy. Amsterdam \& Philadelphia: John Benjamins.

Ward, E. Y. Elliott \& Robert J. Valenza (2011). Shakespeare's vocabulary: Did it dwarf all others? In Ravassat \& Culpeper (Eds.), pp. 34-54.

Warner, Anthony (2012). Early Modern English: Periphrastic DO. In Alexander Bergs \& Laurel Brinton (Eds.), English historical linguistics: An international handbook, Volume 1 (pp. 743-756). Berlin: De Gruyter Mouton.

Wermser, Richard (1976). Statistische Studien zur Entwicklung des englischen Wortschatzes (Schweizer Anglistische Arbeiten 91). Bern: Francke.

Wyld, Henry Cecil (1920). A history of Modern Colloquial English. London: T. Fisher Unwin, Ltd. 